\title{
Overloading study of ionized compounds in hydrophilic interaction chromatography
}

Inga Baškirova,

Vilma Olšauskaitè,

Audrius Padarauskas ${ }^{\star}$

Department of Analytical and

Environmental Chemistry,

Faculty of Chemistry and Geosciences,

Vilnius University,

Naugarduko St. 24,

03225 Vilnius, Lithuania
The overloading behaviour of charged acidic (acetylsalicylic acid and nicotinic acid) and basic (creatinine and 1-ethyl-2,3-dimethylimidazolium) solutes was investigated on two stationary phases (bare silica and amidebonded silica) in the hydrophilic interaction chromatography separation mode at three mobile phase $\mathrm{pH}$ values $(3.0,5.0$ and 7.0$)$. On the bare silica both cationic solutes showed the increased peak tailing as the sample load increased. However, on the amide phase they exhibited a quite different overloading behaviour. The peak shapes for creatinine showed the increased tailing whereas for 1-ethyl-2,3-dimethylimidazolium peak fronting occurs with the sample load. Anionic solutes on both phases showed the increased peak fronting as the sample load increased. In neutral and slightly acidic mobile phases the loadability of the bare silica phase was much higher for bases than for acids. In addition, the loading capacity for the bases increases with $\mathrm{pH}$ whereas an opposite trend was observed for the acidic compounds. The amide phase gave similar loading capacity values for both types of solutes and its loadability is less sensitive to $\mathrm{pH}$ changes, compared to that of bare silica. The obtained results indicate that ionic interactions with dissociated surface silanols play an important role in the overloading behaviour of charged solutes.

Keywords: hydrophilic interaction chromatography, charged solutes, overloading behaviour

\section{INTRODUCTION}

The peak shape and width are very important in chromatography for resolution enhancement and separation improvement. Although many factors contribute to the peak shape and width, the mass overload is perhaps one of the main reasons of the deterioration in column performance in separations by high performance liquid chromatography (HPLC) techniques. The mass (sometimes also called 'concentration') overload results in the con-

*Corresponding author. Email: audrius.padarauskas@chf.vu.lt centration range of the solute in the stationary phase reaching a non-linear part of the sorption isotherm and results in distorted peaks. The specific peak shape observed under mass overload conditions depends on the shape of the sorption isotherm. The so-called Langmuir isotherms have a convex curvature and give rise to tailing peaks. Anti-Langmuir isotherms have a concave curvature and show peaks having a diffuse front and a steep rear (i.e. fronting peaks) [1, 2].

Column overloading is of a special interest to the pharmaceutical industry, e.g. in the determination of impurities. Here, it is necessary to inject 
large sample sizes to enable detection of small impurity peaks, which, however, may be obscured by broad or tailing signals from the major constituents. Reversed-phase (RP) separations using silica phases bonded with alkyl ligands have for many years dominated in the field of HPLC, due to many advantages of this technique [3]. However, the separation of small, ionizable compounds remains challenging with this technique. Such compounds are usually poorly or even not retained under RP-HPLC conditions. In addition, column overloading and its deleterious effect on the peak shape is quite common with such solutes even when surprisingly small amounts of the solute are injected [ [4]. Experimental and theoretical models on overloading of ionized solutes on RP-HPLC columns have been examined in detail [5-8].

Hydrophilic interaction chromatography (HILIC) is a feasible alternative for the separation of highly polar ionizable compounds. This separation technique uses a polar stationary phase (for example, unmodified silica or a polar bonded phase) in conjunction with a polar mobile phase containing more than $60-70 \%$ of an organic solvent (typically acetonitrile) in an aqueous buffer. The term HILIC was first suggested by Alpert in 1990, who explained its principles and some important applications [9]. However, HILIC did not become widely recognized as a distinct chromatographic mode until it was 'rediscovered' by the scientific community in the mid of the first decade of this century [10]. The rising popularity of HILIC over the last decade coincided with a wider availability of specifically designed HILIC stationary phases with diverse functionalities, which could offer different selectivity and higher retention for polar compounds [11].

Despite a large number of publications dealing with the separation of ionizable compounds under HILIC conditions, only few efforts have been made to investigate the overloading behaviour of such compounds in the HILIC separation mode 12-14. However, these studies have focused only on the overloading of basic solutes on bare silica stationary phases.

In the present work, we have investigated the overloading behaviour of some acidic and basic compounds at different mobile phase $\mathrm{pH}$ on the two most popular HILIC stationary phases (bare silica and amide-bonded silica).

\section{EXPERIMENTAL}

Acetonitrile (ACN), acetic acid, formic acid, ammonium acetate and ammonium formate were of LC-MS grade and purchased from Sigma-Aldrich (St. Louis, MO, USA). Acetylsalicylic acid ( $\geq 99 \%)$, creatinine ( $\geq 98 \%)$, 1-ethyl-2,3-dimethylimidazolium tetrafluoroborate $(\geq 98 \%)$ and nicotinic acid $(\geq 98 \%)$ were also from Sigma-Aldrich.

Individual stock solutions of analytes at a concentration of $2.50 \mathrm{~g} / \mathrm{L}$ were prepared in an $\mathrm{ACN} /$ $\mathrm{H}_{2} \mathrm{O}(1: 1, \mathrm{v} / \mathrm{v})$ solution containing $25 \mathrm{mmol} / \mathrm{L}$ of an appropriate buffer. The working standard solutions were prepared by diluting the stock solution with an appropriate mobile phase. The $\mathrm{pH} 3.0 \mathrm{am}-$ monium formate and $\mathrm{pH} 5.0$ ammonium acetate buffers were prepared by adjusting the ammonium formate or ammonium acetate solution with formic or acetic acid. The $\mathrm{pH} 7.0$ buffer was prepared by dissolving an appropriate amount of ammonium acetate salt in water.

HILIC separations were performed on a model 1290 Infinity ultra-high pressure liquid chromatograph from Agilent Technologies (Waldbronn, Germany) including a binary pump, an autosampler, and a photodiode array detector. Acquity UPLC BEH HILIC (bare silica) and Acquity UPLC $\mathrm{BEH}$ Amide (silica coated with amide functional groups) columns $(2.1 \times 100 \mathrm{~mm}, 1.7 \mu \mathrm{m}$, Waters $)$ were used in the experiments. Acetonitrile-water mixtures with the $5 \mathrm{mmol} / \mathrm{L}$ of appropriate buffer were used as mobile phases. For the large retention factor $k$, the proportion of the injected solute amount held in the stationary phase is greater. Consequently, the reduction in efficiency for the same amount of the solute should be greater for stronger retained solutes. In order to facilitate comparison of results the acetonitrile concentration in the mobile phases was adjusted to give a similar retention factor $(\sim 4)$ for each solute with both columns and with each mobile phase. The column temperature was maintained at $25^{\circ} \mathrm{C}$ in all experiments. The mobile phase flow rate was $0.25 \mathrm{~mL} / \mathrm{min}$. The injection volume was $2 \mu \mathrm{L}$. In all experiments, the columns were first equilibrated with the mobile phase for at least $45 \mathrm{~min}$. The column efficiency $(\mathrm{N})$ was determined from peak widths at half height. The column dead time was measured by injection of toluene. All results were the mean of at least duplicate injections. 
Data collection and management was performed by the Agilent MassHunter software.

\section{RESULTS AND DISCUSSION}

\section{Characterization of the solutes}

We selected four compounds as model solutes to examine their overloading behaviour in HILIC. The chemical structures of the solutes are presented in Fig. 1 and their $\mathrm{p} K_{\mathrm{a}}$ and $\log D$ values are listed in Table 1. These compounds are very hydrophilic with $\log D$ values ranging between -0.85 and -2.34 . The $\log D$ value for 1-ethyl-2,3-dimethylimidazolium was not available. Nonetheless, 1-ethyl-2,3-dimethylimidazolium seems to be more hydrophilic than creatinine because it is stronger retained on the both HILIC phases.<smiles>CN1CC(=O)NC1=N</smiles>

Creatinine<smiles>CC(=O)Oc1ccccc1C(=O)O</smiles>

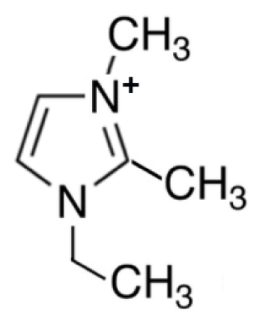

1-Ethyl-2,3-dimethylimidazolium<smiles>O=C(O)c1cccnc1</smiles>

Nicotinic acid
Fig. 1. Structures of the model solutes

Table 1. Properties of model solutes [15]

\begin{tabular}{c|c|c}
\hline Solute & $\mathbf{p} \boldsymbol{K}_{\mathrm{a}}$ & $\log \mathbf{D}$ \\
\hline Creatinine & $\mathrm{p} K_{\mathrm{a} 1}=4.8$ & $-1.02(\mathrm{pH} \mathrm{6.8)}$ \\
& $\mathrm{p} K_{\mathrm{a} 2}=9.2$ & \\
\hline $\begin{array}{c}\text { 1-Ethyl-2,3-dimethyl- } \\
\text { imidazolium }\end{array}$ & - & - \\
\hline Acetylsalicylic acid & $\mathrm{p} K_{\mathrm{a}}=3.5$ & $-0.85(\mathrm{pH} \mathrm{6.8)}$ \\
\hline & $\mathrm{p} K_{\mathrm{a}}=2.2$ & \\
(basic) & $-2.34(\mathrm{pH} \mathrm{7.0)}$ \\
Nicotinic acid & $\mathrm{p} K_{\mathrm{a} 2}=4.8$ \\
& (acidic) & \\
\hline
\end{tabular}

Two of the solutes (creatinine and 1-ethyl-2,3dimethylimidazolium) are positively charged in the $\mathrm{pH}$ range (3-7) studied. 1-Ethyl-2,3-dimethylimidazolium, a quaternary ammonium compound, is permanently positively charged, independent of the $\mathrm{pH}$ of its solution, whereas the net positive charge of creatinine will increase with decreasing $\mathrm{pH}$. Acetylsalicylic acid carries a partial or full negative charge in the $\mathrm{pH}$ range investigated. Nicotinic acid contains both a carboxylic group and an amino group therefore, depending on the $\mathrm{pH}$, may be negatively or positively charged (see the comments below).

\section{Overloading properties on the BEH HILIC column}

Figure 2 shows the overlaid peak profiles of the cationic solutes obtained on the BEH HILIC column when increasing concentrations (up to $1000 \mathrm{mg} / \mathrm{L}$ ) of each solute were injected at three mobile phase $\mathrm{pH}$ values. The higher solute concentrations were not investigated due to the limited solubility in acetonitrile-rich HILIC mobile phases. For purposes of simplicity, only 6 plots at different sample load are presented for each solute, although 12 data points were actually measured. As all samples were prepared in the corresponding mobile phases, the possibility of $\mathrm{pH}$-mismatching to bring on the deterioration could be excluded. While peaks of the smallest concentrations are almost symmetrical, broadening with peak tailing takes place as the sample load increased. Also, retention times move to shorter values with increasing the sample load. The presence of tailing suggests the Langmuir sorption behaviour. Such behaviour is mostly observed for ionized compounds in RP-HPLC separations [⿰亻⿻乚㇒日]. The peak tailing effect was significantly strongly pronounced at $\mathrm{pH}$ 3.0. A possible explanation of this effect is that at low $\mathrm{pH}$, ionization of surface silanols should be substantially suppressed. The removal of negatively charged retention sites may be responsible for the reduced column capacity at lower $\mathrm{pH}$.

Figure 3 shows similar plots for acetylsalicylic and nicotinic acids. As can be seen, at pH 5.0 and 7.0, both solutes showed the increased peak fronting as the sample load increased. The fronting could be due to the anti-Langmuir sorption behaviour [12]. Häglund and Ståhlberg [16] explained the increased overloading of anionic compounds in RP-HPLC as being due to mutual repulsion of the similarly charged ions occurring on 


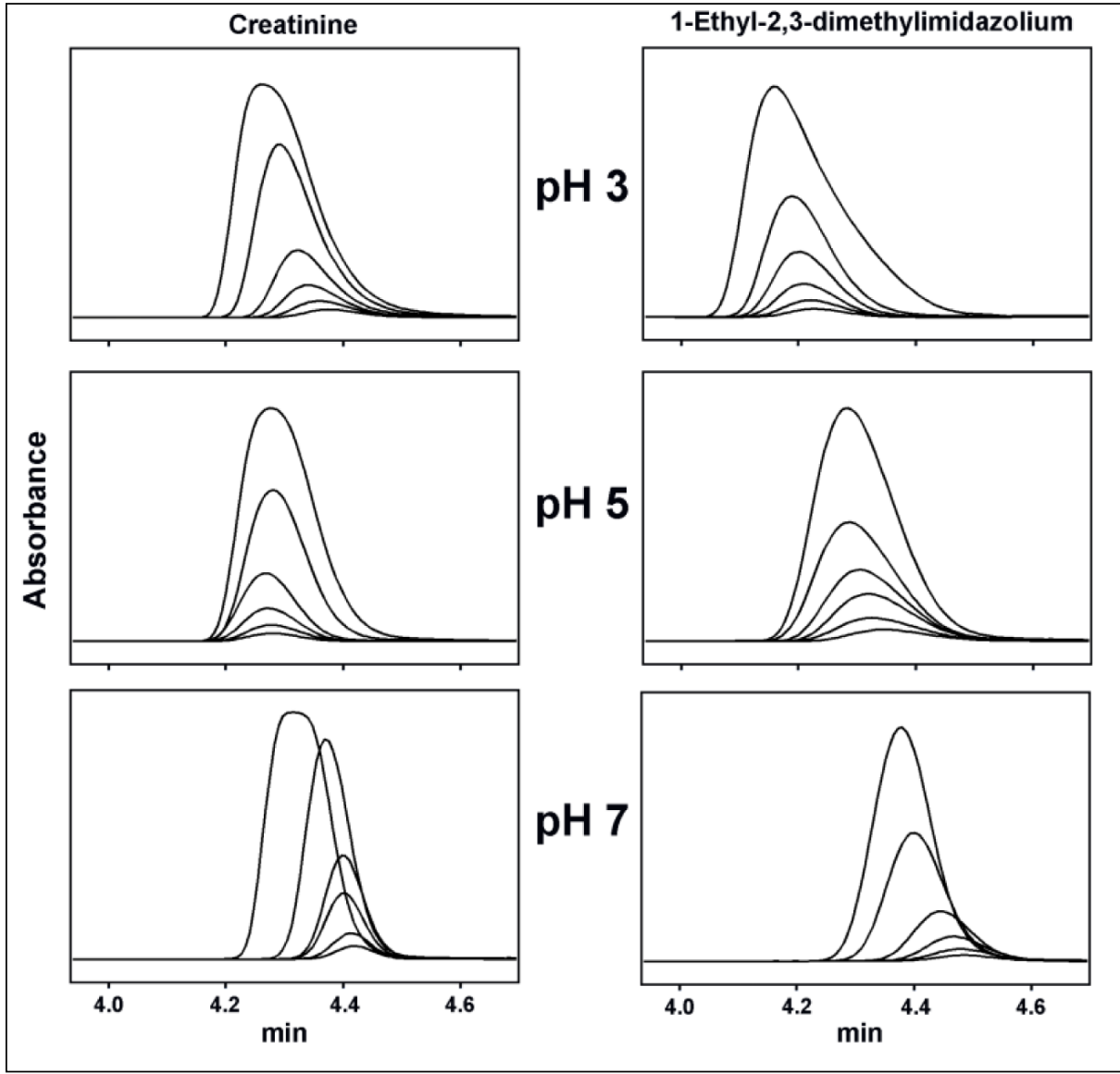

Fig. 2. Overlaid peak profiles of basic solutes recorded on the BEH HILIC column at various pH values

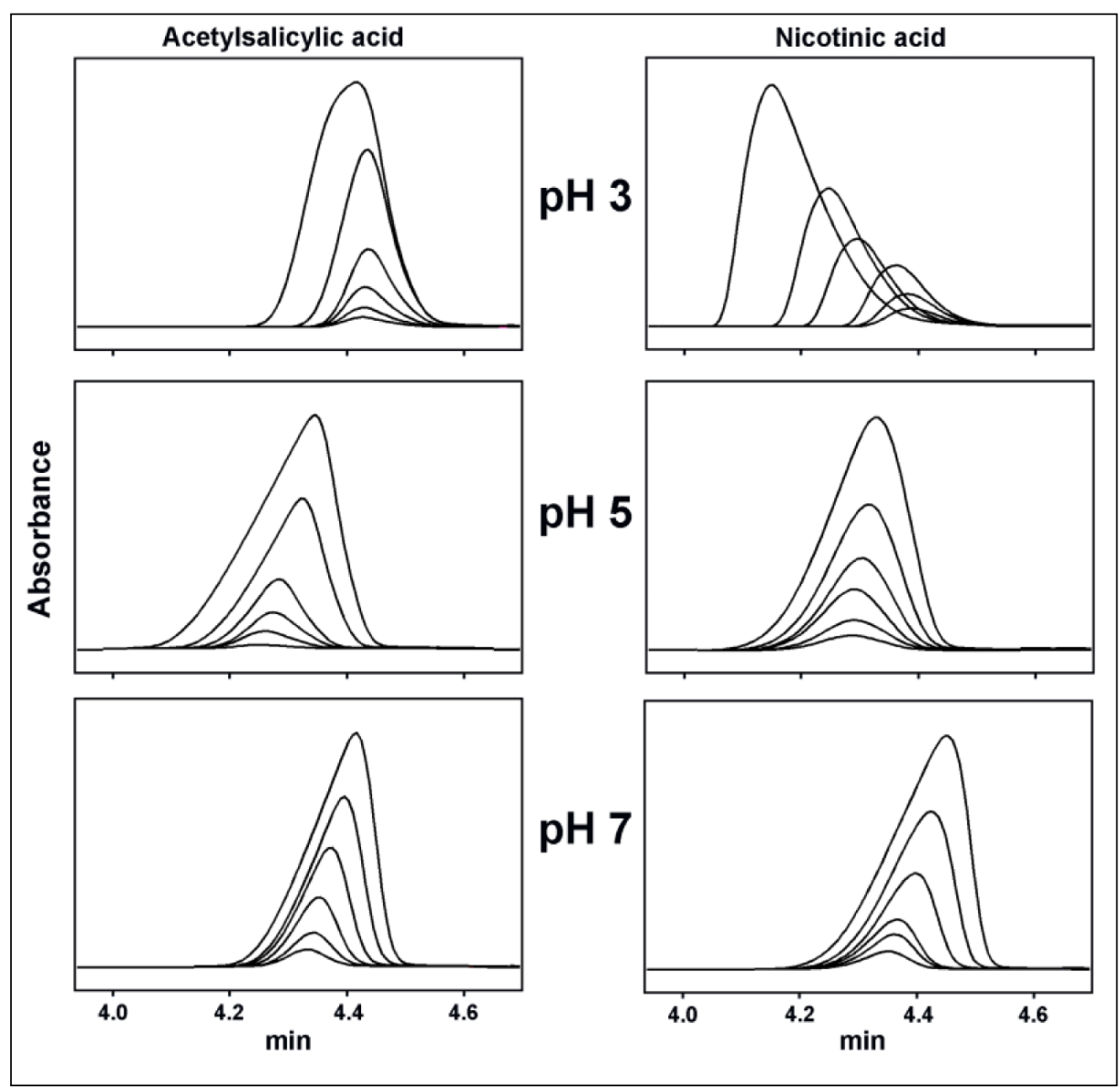

Fig. 3. Overlaid peak profiles of acidic solutes recorded on the BEH HILIC column at various pH values 
the surface of the stationary phase. Thus, it is very likely that the mutual repulsion is also responsible for the overloading of anionic solutes in HILIC on the bare silica phase. Deterioration in the acetylsalicylic acid peak shapes with the sample load was considerably less at $\mathrm{pH}$ 3.0. At this $\mathrm{pH}$, the negative charge of the weakly acidic solute should be significantly reduced causing suppression of ionic repulsion.

Finally, a quite different pattern was obtained for nicotinic acid at $\mathrm{pH}$ 3.0. Under acidic conditions nicotinic acid shows the tailing overload behaviour similar to that obtained for the cationic compounds. This result can be attributed to the zwitterionic nature of the solute. Nicotinic acid contains an amine group $\left(\mathrm{p} K_{\mathrm{a} 1}=2.2\right)$ and a carboxylic group $\left(\mathrm{p} K_{\mathrm{a} 2}=4.8\right)$. Consequently, at weakly acidic and neutral pHs, the amine group is neutral, whereas the carboxylic group is partially or completely deprotonated and the solute carries a net negative charge. Under acidic conditions ( $\mathrm{pH}$ 3.0), due to the protonation of both functionalities the solute is converted into a positively charged form.

\section{Overloading properties on the BEH Amide column}

Figure 4 illustrates the overlaid peak profiles of the cationic solutes measured for different sample loads on the BEH Amide column at three mobile phase $\mathrm{pH}$ values. Surprisingly, on the amide phase cationic solutes exhibited a quite different overloading behaviour. The peak shapes for creatinine showed the increased tailing with the increased sample load. This behaviour is similar to that obtained on the BEH HILIC column. By contrast, for 1-ethyl-2,3-dimethylimidazolium cation peak fronting with increased retention occurs as the sample load increased. However, such different behaviour is difficult to explain. The amide groups of the chemically bonded amide phase lack basic properties and their protonation seems unlikely in the $\mathrm{pH}$ range used in this work. In addition, this phase does not contain negatively charged silanol groups other than unreacted residual silanols. Thus, the overloading behaviour of charged compounds on the amide phase cannot be explained on the basis of ionic solute-silanol interactions alone.

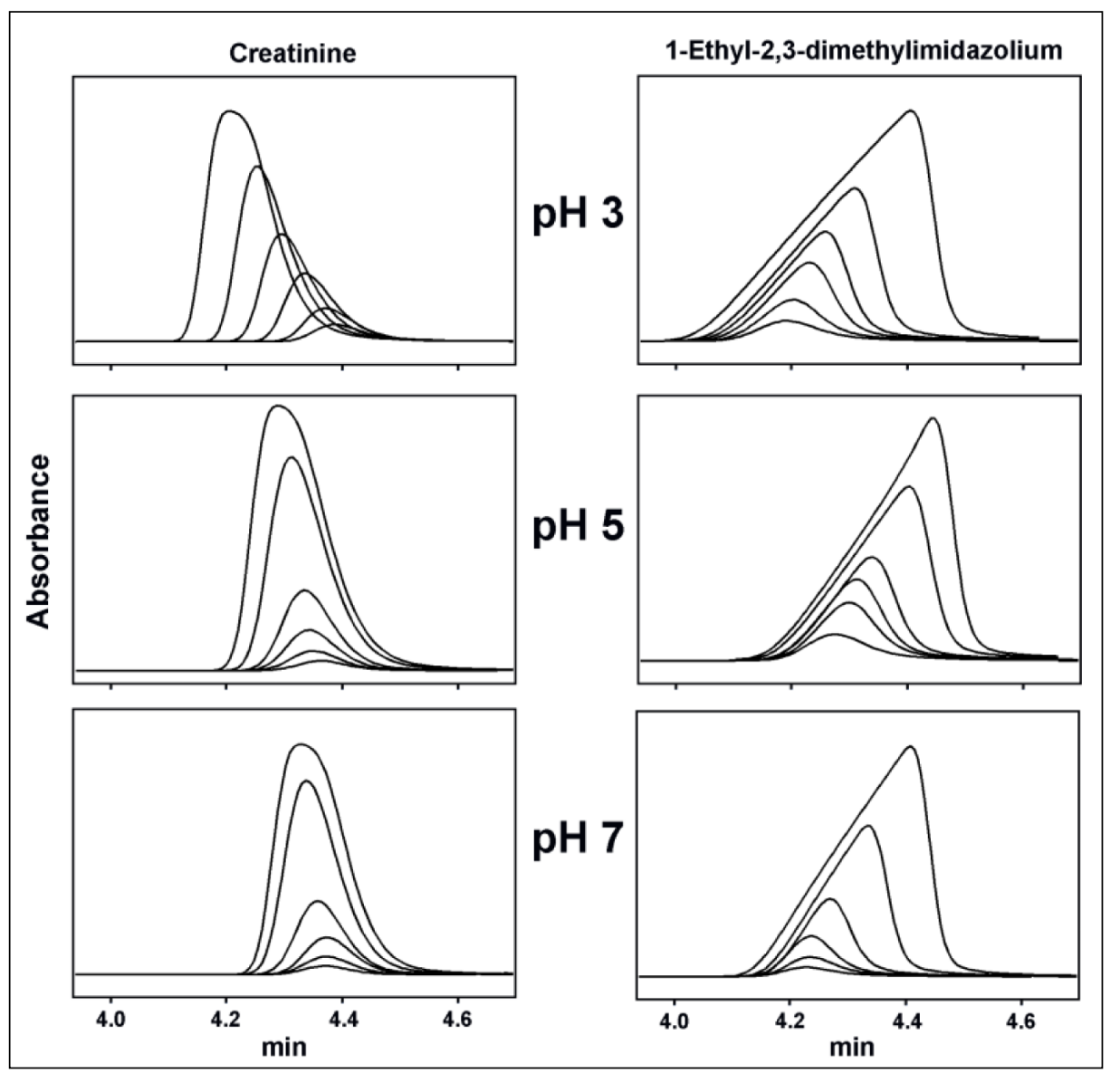

Fig. 4. Overlaid peak profiles of basic solutes recorded on the BEH Amide column at various pH values 
Similarly, McCalley [12] observed a different overloading behaviour of the ionized bases under HILIC conditions on the bare silica phase. Two bases, nortriptyline and diphenhydramine, showed the increased fronting as the sample load increased, whereas procainamide showed the increasing tailing with the increasing load. According to the author, such results may be attributed to a different hydrophilicity of the bases. Fronting in HILIC could be due to the anti-Langmuir sorption behaviour, where solute-solute interactions cause increased retention as the sample load increases. It is possible that the solute-solute interactions for less hydrophilic bases such as nortriptyline and diphenhydramine could be promoted in the environment of a bound layer of water on the stationary phase. In contrast, procainamide is a considerably more hydrophilic base, so the solute-solute interactions may not be promoted. However, in our study an opposite trend was observed: less hydrophilic creatinine showed peak tailing whereas more hydrophilic (i.e. stronger retained in HILIC) 1-ethyl-2,3-dimethylimidazolium showed fronting of peaks with the sample load. Clearly, further studies are needed to explain these contradictions.
The overlaid peak profiles of acetylsalicylic and nicotinic acids obtained on the BEH Amide column at three mobile phase $\mathrm{pH}$ values are given in Fig. 5. A visual comparison of Figs. 3 and 5 shows that the overloaded peak profiles recorded on both BEH HILIC and BEH Amide columns are very similar. Thus, it seems that the mutual repulsion of solutes of the same charge is most likely to be responsible for overload of the acidic compounds on both phases.

\section{Loadability comparison}

For a quantitative evaluation of column loadability, a simple empirical method was proposed by McCalley et al. [17]. This approach involves the measurement of two parameters: the limiting plate count $N_{0}$ and the sample loading capacity $\mathrm{c}_{0.5}$. The limiting plate count is the column efficiency that should be observed when the amount of the solute injected is so small that a linear isotherm pertains. The sample loading capacity is the solute concentration that leads to the plate count equal to half of the limiting plate count $N_{0}$. However, due to the limited solubility of the ionized solutes in acetonitrile-rich HILIC mobile

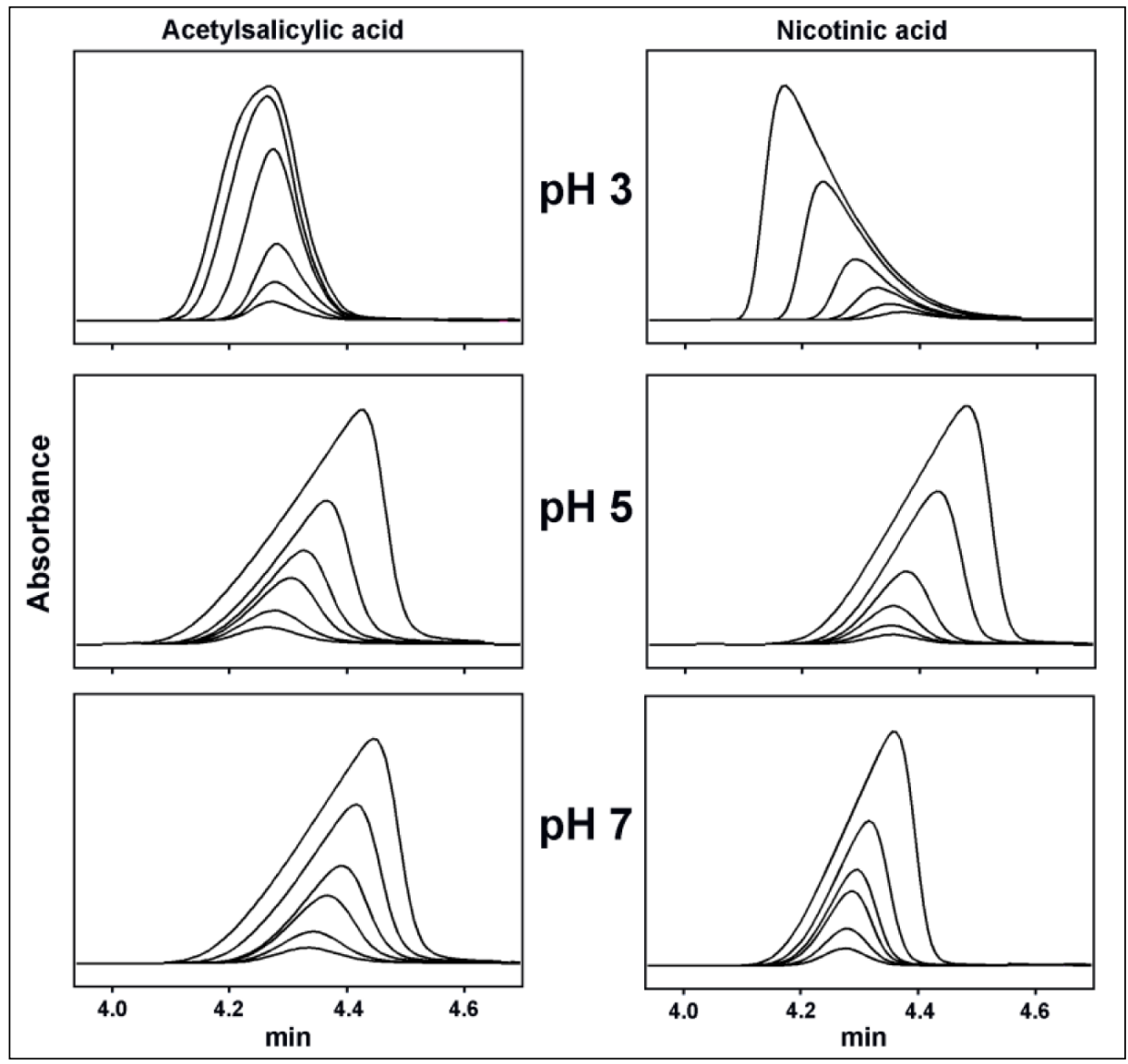

Fig. 5. Overlaid peak profiles of the acidic solutes recorded on the BEH Amide column at various $\mathrm{pH}$ values 
phases, the $50 \%$ reduction of the initial efficiency for some solutes could not be reached. Therefore, in the present study, the sample loading capacity $\mathrm{C}_{0.8}$ was measured which corresponds to the solute concentration that leads to a $20 \%$ loss in $N_{0}$.

Figure 6 shows the plots of BEH HILIC column efficiency for all solutes as a function of the solute mass loaded at three $\mathrm{pH}$ values. Figure 7 shows similar loading plots obtained on the BEH Amide column. These plots provide a simple visual indication of the effects of overload. Sample loading capacity values calculated for different columns, solutes and pHs are presented in Table 2. As can be observed, in neutral and slightly acidic mobile phases, the loadability of the BEH HILIC column was much higher for bases than for acids. For example, $\mathrm{c}_{0.8}$ for cre- atinine and 1-ethyl-2,3-dimethylimidazolium at $\mathrm{pH} 7.0$ were 5.3 and $>8.0 \mathrm{mmol} / \mathrm{L}$, respectively, compared with 1.2 and $1.5 \mathrm{mmol} / \mathrm{L}$ for acetylsalicylic acid and nicotinic acid, respectively. In addition, using the bare silica phase the loading capacity for bases increases with $\mathrm{pH}$ whereas an opposite trend was observed for acidic compounds. As a result, at $\mathrm{pH} 3.0$ the loadability of the BEH HILIC column for all solutes became similar. The obtained results indicate that ionic interactions with dissociated surface silanols play an important role in the overloading behaviour of the charged solutes on the bare silica phase. Thus, in order to maximize the loadability of the bare silica phase, the separation of acidic solutes should be performed at acidic $\mathrm{pH}$, and that of basic solutes should be performed at neutral $\mathrm{pH}$.

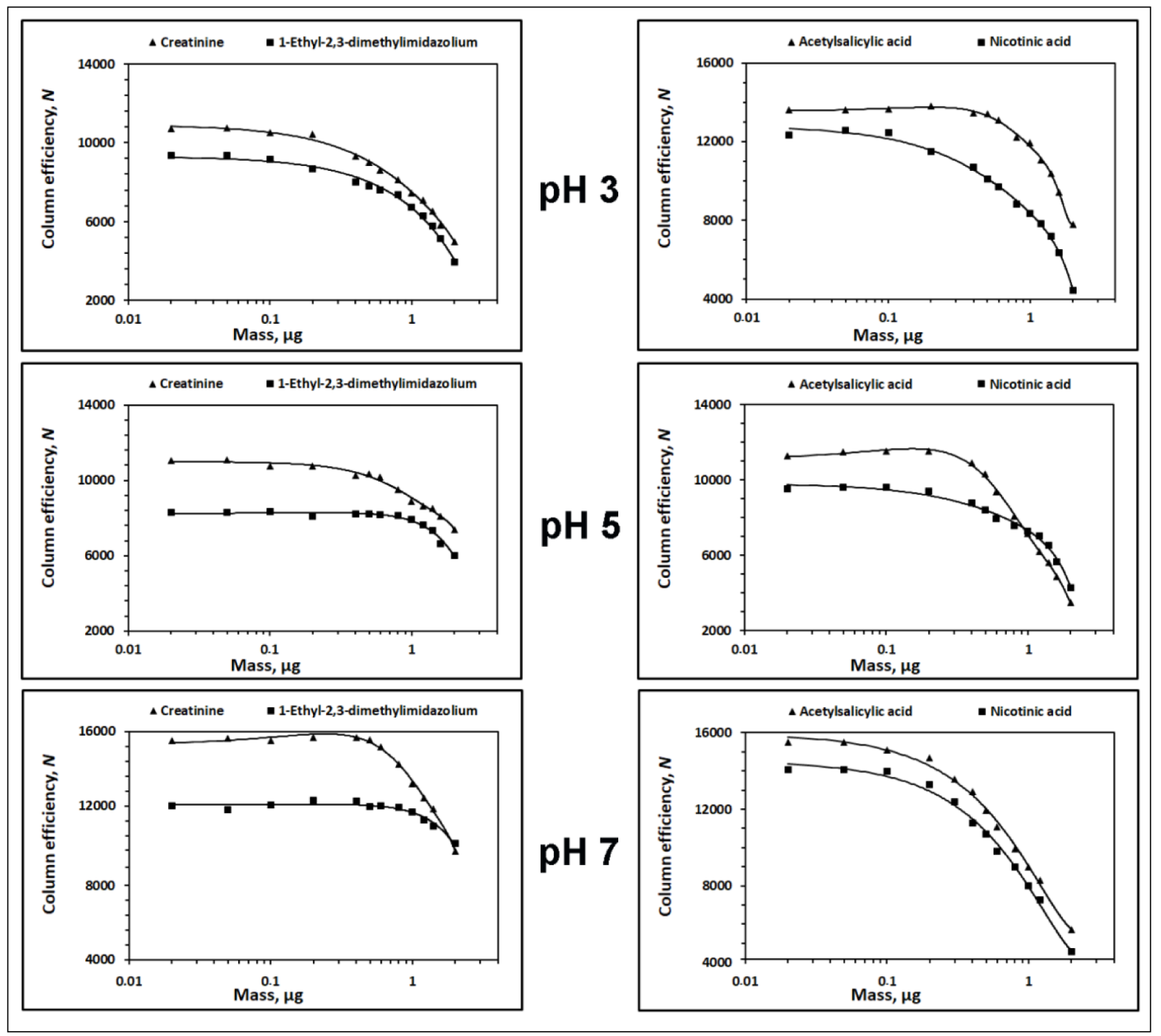

Fig. 6. The plot of column efficiency vs mass of solute on the BEH HILIC column at various pH values 


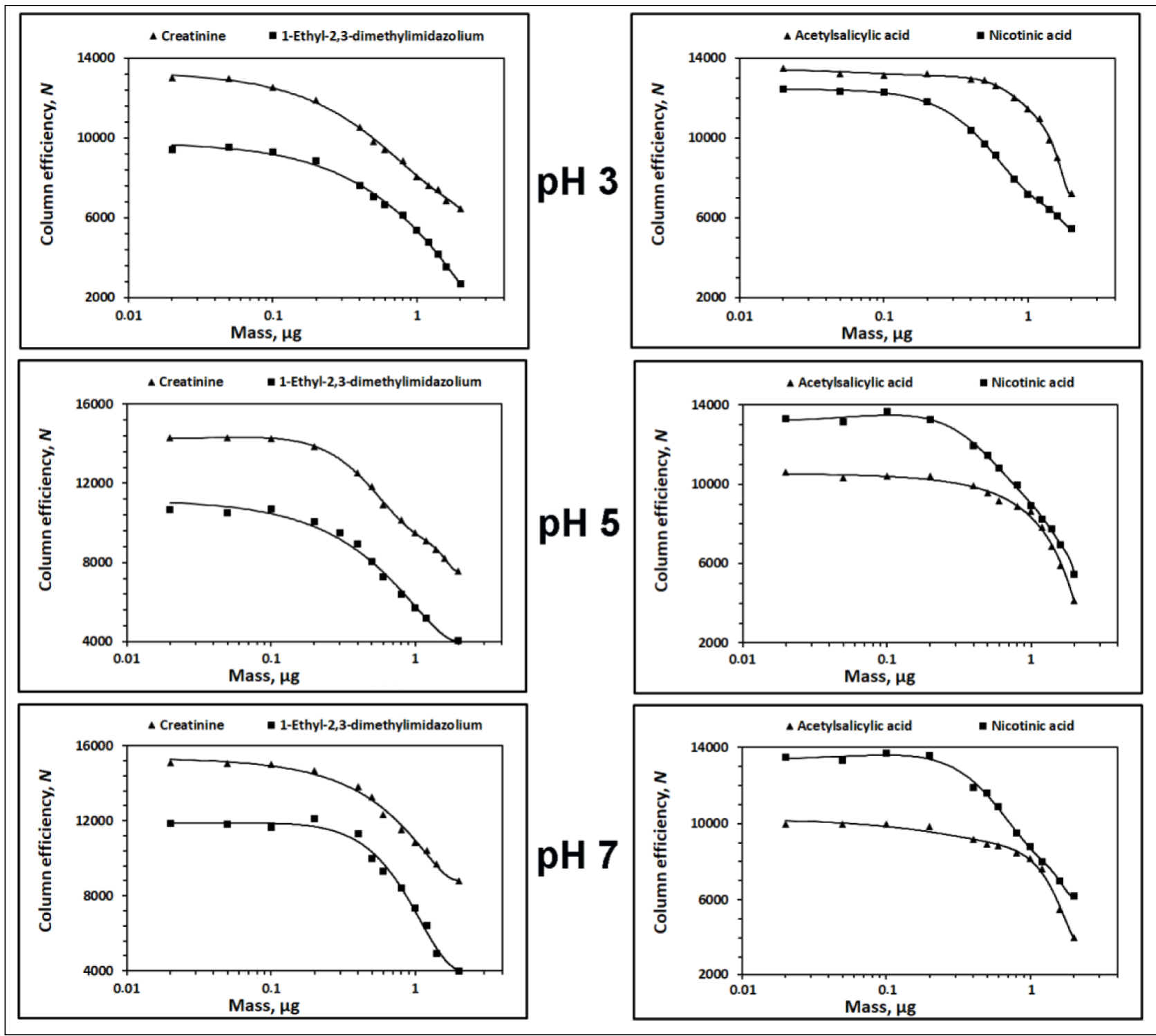

Fig. 7. The plot of column efficiency vs mass of solute on the BEH Amide column at various pH values

Table 2. Sample loading capacity (c0.8) values for different columns, solutes and pHs

\begin{tabular}{c|c|c|c|c}
\hline \multirow{2}{*}{ Column } & \multirow{2}{*}{ Solute } & \multicolumn{3}{c}{$\mathbf{c}_{\mathbf{0 . 8}}, \mathbf{~} \mathbf{\text { mol} / \mathbf { L }}$} \\
\cline { 2 - 5 } & & $\mathbf{p H ~ 7 . 0}$ & $\mathbf{p H ~ 5 . 0}$ & $\mathbf{p H ~ 3 . 0}$ \\
\hline \multirow{2}{*}{ BEH HILIC } & Creatinine & 5.3 & 4.4 & 2.7 \\
\cline { 2 - 5 } & 1-Ethyl-2,3-dimethylimidazolium & $>8.0$ & 6.5 & 2.8 \\
\cline { 2 - 5 } & Acetylsalicylic acid & 1.2 & 1.7 & 3.3 \\
\cline { 2 - 5 } & Nicotinic acid & 1.5 & 2.6 & 2.0 \\
\hline \multirow{2}{*}{ BEH Amide } & Creatinine & 2.8 & 2.2 & 1.8 \\
\cline { 2 - 5 } & 1-Ethyl-2,3-dimethylimidazolium & 2.1 & 1.8 & 1.5 \\
\cline { 2 - 5 } & Acetylsalicylic acid & 3.2 & 3.4 & 3.4 \\
\cline { 2 - 5 } & Nicotinic acid & 2.4 & 2.5 & 1.8 \\
\hline
\end{tabular}

The BEH Amide column gave similar loading capacity values for both types of solutes. In addition, its loadability is less sensitive to $\mathrm{pH}$ changes, compared to that of the BEH HILIC column. Such results could be attributed to a considerably lower density of free silanol groups on the amide phase. 


\section{CONCLUSIONS}

The overloading performance of two HILIC stationary phases (bare silica and amide-bonded silica) was compared using acidic and basic compounds as model solutes. The loading capacity of bare silica for basic solutes can be considerably enhanced by working at neutral $\mathrm{pH}$. In contrast, a better loadability of acidic compounds was obtained at low $\mathrm{pH}$. The amide phase showed a relatively little difference in the loading properties for both acidic and basic solutes and its loadability is less sensitive to $\mathrm{pH}$ changes. From a practical viewpoint, the bare silica phase is recommended for the analysis of basic solutes whereas for acidic solutes the amide phase is preferred.

Received 21 September 2018 Accepted 8 October 2018

\section{References}

1. T. Fornsted, G. Guiochon, Anal. Chem., 66, 2686 (1994).

2. R. Arnell, P. Forssen, T. Fornsted, Anal. Chem., 79, 5838 (2007).

3. L. R. Snyder, J. J. Kirkland, J. W. Dolan, Introduction to Modern Liquid Chromatography, 3th edn., John Wiley \& Sons, Inc., Hoboken, NJ (2010).

4. D. V. McCalley, J. Chromatogr. A, 1217, 858 (2010).

5. D. V. McCalley, Anal. Chem., 78, 2532 (2006).

6. F. Gritti, G. Guiochon, J. Chromatogr. A, 1216, 63 (2009).

7. F. Gritti, G. Guiochon, J. Chromatogr. A, 1254, 30 (2012).

8. M. M. Fallas, S. M. C. Buckenmaier, D. V. McCalley, J. Chromatogr. A, 1235, 49 (2012).

9. A. J. Alpert, J. Chromatogr., 499, 177 (1990).

10. P. Hemström, K. Irgum, J. Sep. Sci., 29, 1784 (2006).

11. B. Buszewski, S. Noga, Anal. Bioanal. Chem., 402, 231 (2012).
12. D. V. McCalley, J. Chromatogr. A, 1171, 46 (2007).

13. D. V. McCalley, J. Chromatogr. A, 1193, 85 (2008).

14. A. Orentienè, V. Olšauskaitè, V. Vičkačkaitè, A. Padarauskas, J. Chromatogr. A, 1218, 6884 (2011).

15. PubChem Compound Database [https://www.ncbi. nlm.nih.gov/pccompound].

16. I. Häglund, J. Ståhlberg, J. Chromatogr. A, 761, 3 (1997).

17. J. Dai, P. W. Carr, D. V. McCalley, J. Chromatogr. A, 1216, 2474 (2009).

Inga Baškirova, Vilma Olšauskaitė, Audrius Padarauskas

\section{JONIZUOTUU JUNGINIŲ PERKROVOS \\ HIDROFILINĖS SĄVEIKOS \\ CHROMATOGRAFIJOJE TYRIMAS}

Santrauka

Darbe tiriama jonizuotų rūgštinių (acetilsalicilo ir nikotino rūgščių) ir bazinių (kreatinino ir 1-etil-2,3-dimetilimidazolio) junginių perkrova ant dviejų sorbentų (nemodifikuoto silikagelio ir amido ligandais padengto silikagelio) hidrofilinès sąveikos chromatografijos sąlygomis. Perkrova buvo tiriama trijų $\mathrm{pH}$ verčių $(3,0$, 5,0 ir 7,0) judriose fazèse. Didinant ịleidžiamą baziniu junginiu kieki nemodifikuoto silikagelio sorbente buvo registruojamos smailès su platėjančiu šleifu. $\mathrm{O}$ amido sorbente bazinių junginių perkrovos elgsena buvo skirtinga: kreatinine buvo registruojamos smailès su šleifu, o 1-etil-2,3-dimetilimidazolyje - su išplitusiu frontu. Rūgštinèse analitėse abiejuose sorbentuose buvo registruojamos smailes su išplitusiu frontu. Neutralioje ir silpnai rūgščioje terpèse silikagelio sorbentas pasižymèjo didesniu atsparumu perkrovai baziniais junginiais. Be to, šio sorbento krovumas baziniams junginiams didejjo didejjant judrios fazès $\mathrm{pH}$. Tuo tarpu rūgštyse buvo nustatyta priešinga tendencija. Amido sorbento krovumas bazèms ir rūgštims buvo panašus ir mažiau jautrus $\mathrm{pH}$ pokyčiams. Tyrimų rezultatai rodo, kad joninès sąveikos su disocijavusiomis silanolinemis grupemis sorbento paviršiuje atlieka svarbų vaidmenį jonizuotų junginių perkrovoje. 
